\title{
PENGEMBANGAN MODUL IPA TERPADU TERINTEGRASI AYAT-AYAT AL-QUR'AN PADA MATERI AIR SEBAGAI SUMBER KEHIDUPAN
}

\author{
Sri Latifah \\ Program Studi Pendidikan Fisika, FTK IAIN Raden Intan Lampung; E-mail: Srilatifah21@yahoo.com \\ Diterima: 11 Juli 2015 Disetujui: 11 Oktober 2015. Dipublikasikan: Oktober 2015
}

\begin{abstract}
This research is a development research that aims to produce Interated IPA module product integrated with Al-Qur'an verses on the material of Water as the source of life, as a teaching material of students of SMP / MTs class VII. The problems in this study include how to develop Integrated IPA module integrated with Qur'anic verses on the material of Water as the Source of Life, and whether the Integrated IPA module development integrated with Qur'anic verses on the material of Water as the Source of Life is interesting to be used as teaching materials. This research is a development research using Research and Development research method $(R \& D)$. The resulting product is categorized very good based on validation from material experts with $85 \%$ percentage and design expert with $85 \%$ score, and module is very interesting to be used as a teaching material based on teacher's assessment to get $86 \%$ score percentage, and students' response on small group test obtained the percentage of $76 \%$ and field trials received a score percentage of $81 \%$..
\end{abstract}

\begin{abstract}
Abstrak: Penelitian ini merupakan penelitian pengembangan yang bertujuan untuk menghasilkan produk berupa modul IPA Terpadu terintegrasi ayat-ayat Al-Qur'an pada materi Air Sebagai Sumber Kehidupan sebagai bahan ajar siswa SMP/MTs kelas VII. Masalah pada penelitian ini antara lain, bagaimana mengembangkan modul IPA Terpadu terintegrasi ayat-ayat Al-Qur'an pada materi Air Sebagai Sumber Kehidupan, dan apakah pengembangan modul IPA Terpadu terintegrasi ayat-ayat Al-Qur'an pada materi Air Sebagai Sumber Kehidupan menarik untuk dijadikan sebagai bahan ajar. Penelitian ini merupakan penelitian pengembangan menggunakan metode penelitian Research and Development $(\mathrm{R} \& \mathrm{D})$. Produk yang dihasilkan terkategori sangat baik berdasarkan validasi dari ahli materi dengan presentase skor $85 \%$ dan ahli desain dengan skor $85 \%$, serta modul sangat menarik untuk dijadikan bahan ajar berdasarkan penilaian guru memperoleh presentase skor $86 \%$, dan respon siswa pada uji coba kelompok kecil memperoleh persentase $76 \%$ serta uji coba lapangan memperoleh presentase skor $81 \%$.
\end{abstract}

Kata kunci :air sebagai sumber kehidupan,integrasi ayat-ayat Al-Qur'an, modul IPA Terpadu

\section{PENDAHULUAN}

Gerbang awal bagi seseorang dalam memperoleh informasi serta wawasan keilmuan yaitu melalui proses pendidikan, dalam pendidikan proses pembelajaran tentu dibutuhkan suatu sumber belajar yang mendukung tujuan yang akan dicapai.

Pendidikan menurut Undang-Undang SISDIKNAS no. 20 tahun 2003, adalah sebagai usaha sadar dan terencana untuk mewujudkan suasana belajar dan proses pembelajaran sedemikian rupa supaya siswa dapat mengembangkan potensi dirinya untuk memiliki kekuatan spiritual keagamaan, pengendalian diri, kepribadian, kecerdasan, akhlak mulia, serta keterampilan dalam bermasyarakat, bangsa dan negara.

Pembelajaran merupakan seperangkat tindakan yang dirancang untuk mendukung proses belajar siswa, dengan memperhitungkan kejadian-kejadian intern yang berlangsung dialami siswa (Trianto, 2012). Dalam pembelajaran juga terdapat tahapan-tahapan yang nantinya 
menjadi acuan untuk menentukan jenis materi pembelajaran, strategi pembelajaran, metode pembelajaran, serta media pembelajaran (Arsyad, 2011). Tanpa tujuan yang jelas, pembelajaran akan menjadi kegiatan tanpa arah, tanpa fokus dan tidak efektif. Pendidikan sangat berperan penting dalam kehidupan manusia, selain menuntut ilmu kewajiban bagi setiap muslim, Allah SWT berjanji akan meningkatkan derajat orang-orang yang berilmu. Telah banyak ayat AlQur'an yang menyebutkan keutamaankeutamaan bagi setiap umat manusia untuk menuntut ilmu, salah satu firman Allah SWT dalam Q.s Al-Mujadalah ayat 11, berbunyi :

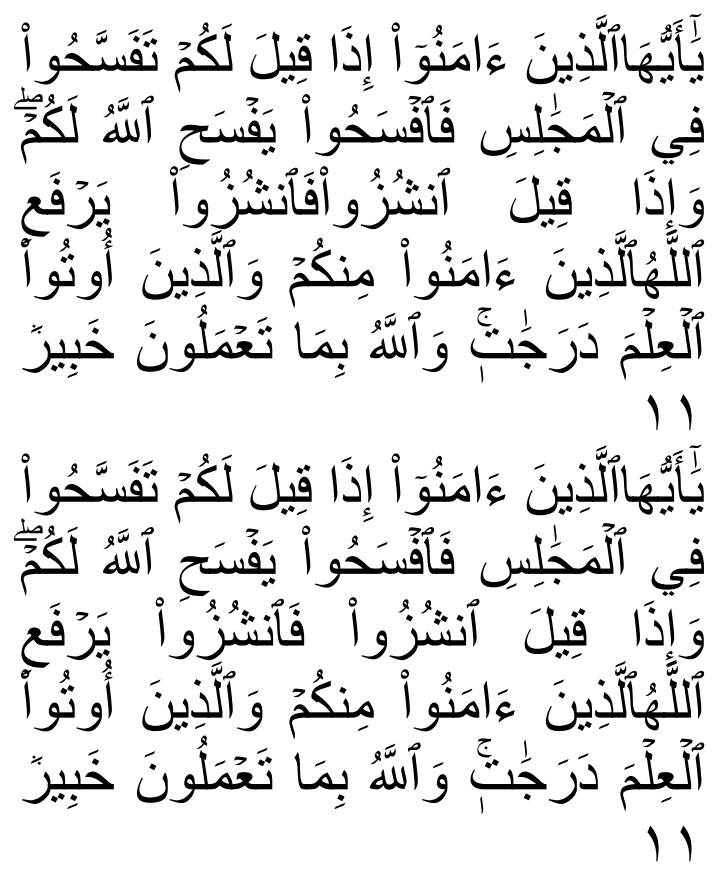

Artinya: Hai orang-orang beriman apabila kamu dikatakan kepadamu: "Berlapang-lapanglah dalam majlis", Maka lapangkanlah niscaya Allah akan memberi kelapangan untukmu. dan apabila dikatakan: "Berdirilah kamu", Maka berdirilah, niscaya Allah akan meninggikan orang-orang yang beriman di antaramu dan orang-orang yang diberi ilmu pengetahuan beberapa derajat. dan Allah Maha mengetahui apa yang kamu kerjakan.

Pembelajaran menggunakan modul menerapkan strategi belajar siswa aktif. (Yuberti, 2014). Karena dalam proses pembelajarannya, siswa tidak lagi berperan sebagai pendengar dan mencatat ceramah guru, tetapi mereka adalah pelajar aktif, meskipun pada prinsipnya modul bersifat individual namun pada saat tertentu atau tugas-tugas siswa dituntut untuk bekerja sama dalam kelompok. Modul yang dijadikan sebagai sumber belajar di sekolah pada umumnya hanya berisikan pengetahuan umum tanpa mengaitkan dengan ayat-ayat yang terkandung dalam Al-Qur'an, sekolah MTs atau setaraf dengan Sekolah Menengah Pertama (SMP) ini memiliki perbedaan, pendidikan Madrasah (MTs) memiliki ciri khas yang memiliki keunikan dari unit sistem pendidikan Nasional yang lain, sebab pada lembaga Madrasah Tsanawiyah menempatkan nilai-nilai Islam dan budaya luhur bangsa sebagai spirit dalam proses pengelolaan dan pembelajaran, menciptakan suasana keagamaan dalam lembaga pendidikan (Thayyarah, (2014). MTs, menekankan kemampuan umum yang diperlukan untuk hidup bermasyarakat dan bernegara. Materi pembelajaran di Madrasah lebih mengutamakan pada pembekalan kemampuan yang fungsional untuk kehidupan dalam berbagai bidang dengan basis pada nilai-nilai ajaran Islam. Ilmu Pengetahuan Alam (IPA) merupakan salah satu mata pelajaran yang wajib diterima oleh siswa. Pemberian mata pelajaran IPA memiliki tujuan agar siswa memperoleh kompetensi ilmu pengetahuan dan teknologi serta membudayakan berpikir ilmiah, kreatif dan mandiri.

Hakikat IPA merupakan gelaja-gejala alam pada dimensi pengetahuan (keilmuan), dengan begitu, pengetahuan 
dapat dikaitkan pada dimensi nilai ukhrawi, dimana dengan memperhatikan keteraturan di alam semesta akan semakin meningkatkan keyakinan akan adanya sebuah kekuatan yang Maha dahsyat yang tidak dapat dibantah lagi, yaitu Allah SWT. Dimensi ini menggambarkan hakikat IPA adalah memautkan antara aspek logika-materil dengan aspek spiritual, yang sementara ini dianggap cakrawala kosong, karena suatu anggapan antara IPA dan agama merupakan dua sisi yang berbeda dan tidak mungkin dipersatukan satu sama lain dalam satu bidang kajian. Pada kenyataannya terdapat benang merah ketertautan di antara keduanya. Berdasarkan pemaparan di atas maka jelas, siswa dalam pembelajaran IPA tidak hanya dituntut untuk mengetahui tentang sains namun juga memahami bahwa keteraturan yang ada dalam alam semesta ini tidak lepas dari kekuasaan Allah SWT sehingga semakin bertambah keyakinan terhadap Tuhan, dan menumbuhan karakter berwawasan keislaman terhadap siswa. Berdasarkan pra penelitian yang telah dilaksanakan dengan subyek guru IPA MTs Islamiyah Sukoharjo, Kabupaten Pringsewu pada kenyataannya bahan ajar yang digunakan sebagai sumber belajar yaitu buku teks atau buku paket, LKS, dan media elektronik dengan menyajikan materi IPA khususnya fisika berisi pengetahuan sains, sedangkan salah satu misi MTs Islamiyah yaitu menyiapkan manusia yang islami. Tujuan MTs yaitu mewujudkan siswaberakhlaq mulia, cerdas, cakap, terampil, percaya diri serta berguna bagi masyarakat bangsa dan negara. Proses pembelajaran IPA Terpadu di Madrasah Tsanawiyah (MTs) belum terlaksana sesuai dengan misi sekolah. Peneliti juga melakukan refleksi diri selama melakukan observasi di beberapa sekolah, antara lain: SMP Negeri 26 Bandar Lampung, MTs Al Hikmah Bandar Lampung, dan SMP N 19 Bandar
Lampung dengan visi sekolah tersebut yaitu mewujudkan sekolah yang bermutu berdasarkan iman dan taqwa. Pra penelitian dengan subyek guru IPA diperoleh informasi bahwa dalam proses pembelajaran IPA masih menggunakan sumber belajar yang menyajikan materi secara sains, serta belum ada modul IPA Terpadu yang terintegrasi ayat-ayat AlQur'an pada materi Air Sebagai Sumber Kehidupan.

Bahan ajar adalah seperangkat materi yang disusun secara sistematis baik tertulis maupun tidak sehingga tercipta lingkungan/suasana yang memungkinkan siswa untuk belajar. Fatmawati (2012) menyatakan bahwa penggunaan modul sebagai bahan ajar dalam kelas merupakan suatu alternatif untuk proses pembelajaran yang menitikberatkan pada keaktifan dan pemahaman siswa. Modul merupakan salah satu bentuk dari bahan ajar. Pengembangan modul ini didukung oleh beberapa hasil penelitian yang menemukan bahwa pembelajaran dengan modul efektif meningkatkan hasil belajar siswa (Fatmawati, 2012). Kelebihan penggunaan bahan ajar modul adalah, modul mampu menjelaskan sesuatu dengan bahasa yang mudah diterima peserta didik sesuai dengan tingkat pengetahuan dan usianya (Depdiknas, 2005). Guru harus memiliki atau menggunakan bahan ajar sesuai dengan kurikulum, karakteristik sasaran, tuntutan pemecahan masalah belajar. Bahan ajar adalah segala bahan yang dapat digunakan untuk membantu guru/instruktur dalam melaksanakan kegiatan belajar mengajar.

Nilai yang terkandung dalam Sains merupakan nilai-nilai agama yang dapat dikembangkan, misalnya dengan menyisipkan ayat-ayat Al-Qur'an (Kauniyah) yang relevan dengan bahasan dalam Sains (Djudin, 2011). Allah menciptakan planet-planet dalam Air Sebagai Sumber Kehidupan yang berjalan 
di atas khittah yang teratur, dan menciptakan wadah dunia untuk manusia agar dapat berinteraksi dengan sekitar, hal tersebut membuktikan bahwa segala sesuatu yang hidup melalui suatu proses. Al-Qur'an berbicara tentang alam semesta, yang meliputi bumi dan langit, unsurnya yang beranekaragam, para penghuninya, serta fenomena-fenomena di dalamnya.

Modul salah satu perangkat pembelajaran yang dibutuhkan dalam proses pembelajaran yang dibuat oleh guru dengan menyesuaikan materi serta kompetensi dasar. Modul digunakan untuk memudahkan peserta didik memahami materi yang disajikan, secara mandiri atau melalui bimbingan guru. Guru melihat bahwa siswa harus melewati kemampuan dan proses intelektual dengan beragam pengalaman (Reid, 1984). Modul merupakan salah satu bentuk bahan ajar yang dikemas secara utuh dan sistematis, di dalamnya memuat seperangkat pengalaman belajar terencana serta didesain untuk membantu peserta didik menguasai tujuan belajar yang spesifik. Modul minimal memuat tujuan pembelajaran, materi/substansi belajar dan evaluasi. Penelitian dan pengembangan tentang modul IPA diantaranya pengembangan modul tematik dan inovatif berkarakter untuk kelas VII SMP (Izzati, 2013) dan pengembangan Modul berbasis LKS yang mencakup ranah kognitif, afektif dan psikomotor (Febriana, 2014).

\section{METODE PENELITIAN}

Pengembangan dilakukan dengan metode penelitian dan pengembangan (Research \& Development). Model pengembangan pada penelitian ini yaitu model Borg and Gall dalam Sugiyono (2012) meliputi: 1) Potensi dan Masalah, 2) Pengumpulan Data, 3) Desain Produk,

4) Validasi desain, 5) Perbaikan Desain, 6) Uji coba produk, 7) Revisi produk, 8)
Uji coba pemakaian, 9) Revisi Produk, 10) Produksi massal. Dalam penelitian ini dibatasi langkah-langkah penelitian pengembangan dari sepuluh langkah menjadi tujuh langkah dikarenakan mengingat waktu dan biaya yang terbatas. Subjek pada penelitian adalah siswa kelas VII MTs Al-Huda Pringsewu, MTs Islamiyah Sukoharjo Pringsewu dan SMP N 26 Bandar Lampung karena beberapa sekolah tersebut memiliki visi misi serta tujuan sekolah yang islami.Data penelitian dikumpulkan dengan menggunakan lembar validasi ahli, lembar penilaian guru dan lembar angket respon siswaserta análisis data menggunakan skala likert.

Sebelum instrumen pengumpulan data ini digunakan, dilakukan kalibrasi instrumen. Kalibrasi dilakukan untuk memenuhi kriteria kelayakan atau kualitas instrumen. Adapun kalibrasi yang dilakukan yaitu:

\section{a. Validitas instrumen}

Validitas ini dilakukan melalui pertimbangan para ahli. Pertimbangan ini memvalidasi isi yang berkaitan dengan butir-butir pernyataan pada angket yang akan diajukan kepada responden.Pertimbangan-pertimbangan tersebut memvalidasi aspek seperti pengembangan indikator, penskoran tiap indikator, pemilihan kata dalam pengembangan indkator, serta kejelasan dan kefektifan bahasa yang digunakan.

\section{b. Reliabilitas instrumen}

Penelitian ini menggunakan angket skala Likert, sehingga digunakan reliabilitas dengan rumus Alpha sebagai berikut: Langkah pertama, menghitung Varians Skor tiap-tiap item dengan rumus:

$$
\mathrm{S}_{\mathrm{i}}=\frac{\sum X_{i}^{2-\frac{\left(\sum X i\right)^{2}}{N}}}{N}
$$


Dimana :

$\mathrm{S}_{\mathrm{i}} \quad=$ Varians skor tiap-tiap item

$\sum X_{i}{ }^{2}=$ Jumlah kuadrat item $\mathrm{X}_{\mathrm{i}}$

$\left(\sum x_{i}\right)^{2}=$ Jumlah item $\mathrm{X}_{\mathrm{i}}$ dikuadratkan

$\mathrm{N} \quad=$ Jumlah responden

Langkah kedua, kemudian menjumlahkan Varians semua item dengan rumus :

Dimana :

$$
\sum S_{1}=\mathrm{S}_{1}+\mathrm{S}_{2}+\mathrm{S}_{3} \ldots \mathrm{S}_{\mathrm{n}}
$$

$\sum S_{1} \quad=$ Jumlah Varians semua item

$\mathrm{S}_{1}+\mathrm{S}_{2}+\mathrm{S}_{3} \ldots \mathrm{S}_{\mathrm{n}}=$ Varians item ke-

$$
1,2,3 \ldots . n
$$

Langkah ketiga, menghitung Varians total dengan rumus :

$$
S_{t}=\frac{\sum X_{t}^{2}-\frac{\left(\sum X_{t}\right)^{2}}{N}}{N}
$$

Dimana :

$$
\begin{array}{ll}
\mathrm{S}_{\mathrm{t}} & =\text { Varians total } \\
\sum_{t} X_{t}{ }^{2} & =\text { Jumlah kuadrat } \mathrm{X} \text { total } \\
\left(\sum X_{t}\right)^{2} & =\text { Jumlah } \mathrm{X} \text { total } \\
\text { dikuadratkan } & \\
N & =\text { Jumlah responden }
\end{array}
$$

Langkah keempat, memasukan nilai alpha dengan rumus :

$$
\mathrm{r}_{11}=\left(\frac{k}{k-1}\right)\left(1-\frac{\sum s_{i}}{S_{t}}\right)
$$

Dengan keputusan membandingkan $\mathrm{r}_{11}$ dengan $r_{\text {tabel }}$

Kaidah keputusan: Jika $r_{11}>r_{\text {tabel }}$ berarti Reliabel dan $\mathrm{r}_{11}<\mathrm{r}_{\text {tabel }}$ berarti Tidak Reliabel.

Berdasarkan hasil uji reliabilitas dan telah melalui perhitungan dengan rumus reliabilitas alpha instrumen dinyatakan reliabel dengan reliabilitas angket 0,89 dimana $\mathrm{r}_{11}>\mathrm{r}_{\text {table.Setelah dilakukan }}$ kalibrasi instrumen, maka angket dapat digunakan dalam penelitian. Untuk menganalisis data angket menggunakan persamaan sebagai berikut.
Persamaan untuk menghitung presentase adalah sebagai berikut :

$$
x_{i}=\frac{\sum \text { Skor }}{\text { Skor }_{\max }} \times 100 \%
$$

Untuk mengetahui kemenarikan modul, responden diberi angket. Mengetahui nilai akhir menggunakan analisis rata-rata untuk butir yang bersangkutan dalam angket yaitu dengan perhitungan jumlah nilai tersebut dibagi dengan banyaknya responden.

Persamaan yang digunakan untuk menentukan nilai rata-rata akhir adalah :

$$
\bar{x}=\frac{\sum X i}{n}
$$

Keterangan:

$$
\begin{array}{ll}
\text { Skor }_{\max } & =\text { Skor maksimal. } \\
\sum_{\bar{x} \text { Skor }} & =\text { Jumlah skor. } \\
\bar{x} & =\text { Rata-rata akhir. } \\
x_{i} & =\text { Jumlah nilai responden. } \\
\mathrm{n} & =\text { Jumlah responden. }
\end{array}
$$

Hasil skor presentase yang diperoleh dari penelitian diinterpretasikan dalam kriteria tabel 1

$$
\text { Tabel } 1 \text { Skala Interpretasi Kriteria }
$$

\begin{tabular}{cc}
\hline Interval & Kriteria \\
\hline $0 \%-20 \%$ & Sangat Kurang Baik \\
\hline $21 \%-40 \%$ & Kurang Baik \\
\hline $41 \%-60 \%$ & Cukup Baik \\
\hline $61 \%-80 \%$ & Baik \\
\hline $81 \%-100 \%$ & Sangat Baik \\
\hline
\end{tabular}

Dengan adanya tabel skala interpretasi kriteria tersebut digunakan sebagai acuan melihat presentase uji coba produk. Jika diperoleh skor dengan interval 0\%-20\% maka modul terkategori sangat kurang menarik, jika diperoleh skor dengan interval 21\%-40\% maka modul terkategori kurang menarik, jika diperoleh skor dengan interval 41\%-60\% maka modul terkategori cukup menarik, jika diperoleh skor dengan interval 61\%- 
$80 \%$ maka modul terkategori menarik, dan jika diperoleh skor dengan interval 81\%-100\% modul terkategori sangant menarik untuk dijadikan sebagai bahan ajar. Indikator kemenarikan siswa terdiri dari tampilan fisik modul dan konten dari modul tersebut.

\section{HASIL DAN PEMBAHASAN}

Validasi dari modul IPA Terpadu terintegrasi ayat-ayat Al-Qur'an pada materi Air Sebagai Sumber Kehidupan dilakukan oleh 6 dosen ahli. Dengan 3 dosen sebagai validator ahli materi dan 3 dosen sebagai validator ahli desain. Berdasarkan penilaian validasi ahli materi terhadap modul IPA Terpadu terintegrasi ayat-ayat Al-Qur'an pada materi Air Sebagai Sumber Kehidupan dianalisis 3 aspek yaitu aspek kelayakan isi, aspek kelayakan penyajian, dan aspek kebahasaan. Pada penilaian ahli desain terhadap modul IPA Terpadu terintegrasi ayat-ayat Al-Qur'an pada materi Air Sebagai Sumber Kehidupan dianalisis 4 aspek yaitu aspek kegrafikan, aspek kelayakan bahasa, pendukung penyajian serta keterkaitan ayat-ayat Al-Qur'an.

Pada penelitian ini dilakukan dua kali validasi, yaitu validasi produk awal dan validasi produk setelah direvisi serta dalam penelitian terhadap responden siswa modul diujicobakan dalam proses pembelajaran menggunakan metode kooperatif tipe STAD (Student Teams Achivement Divisions).

\section{a. Validasi ahli materi}

Tabulasi hasil validasi oleh ahli materi pada produk awal dan produk yang telah diperbaiki disajikan dalam bentuk diagram sebagai berikut ini:

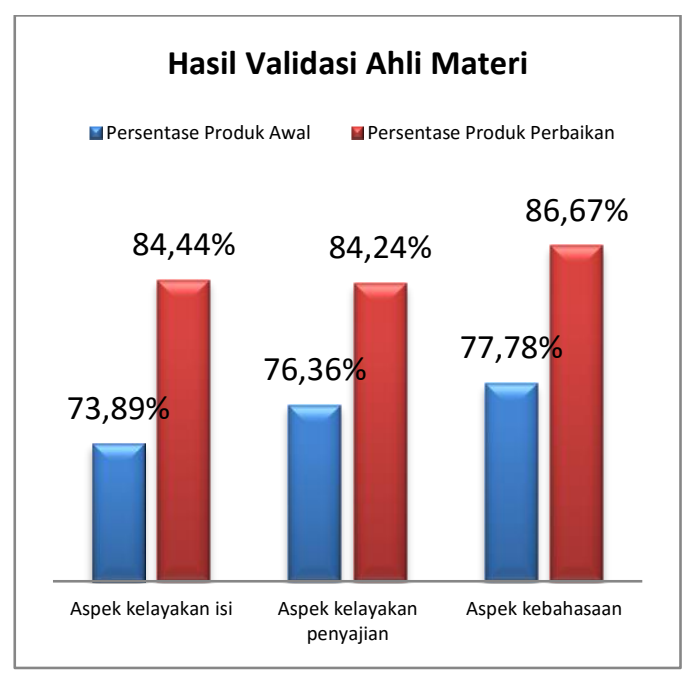

Gambar1. Diagram tabulasi ahli materi

Berdasarkan hasil validasi oleh ahli materi pada produk awal diperoleh skor total 294 dengan presentase $75 \%$ dan berada pada kriteria validasi "baik". Setelah produk direvisi dilakukan validasi kembali, diperoleh skor total 330 dengan presentase $85 \%$ dan berada pada kriteria validasi "sangat baik", terjadi peningkatan skor setelah produk direvisi.

\section{b. Ahli Desain}

Tabulasi hasil validasi oleh ahli desain ada produk awal dan produk yang telah diperbaiki disajikan dalam bentuk diagram sebagai berikut ini:

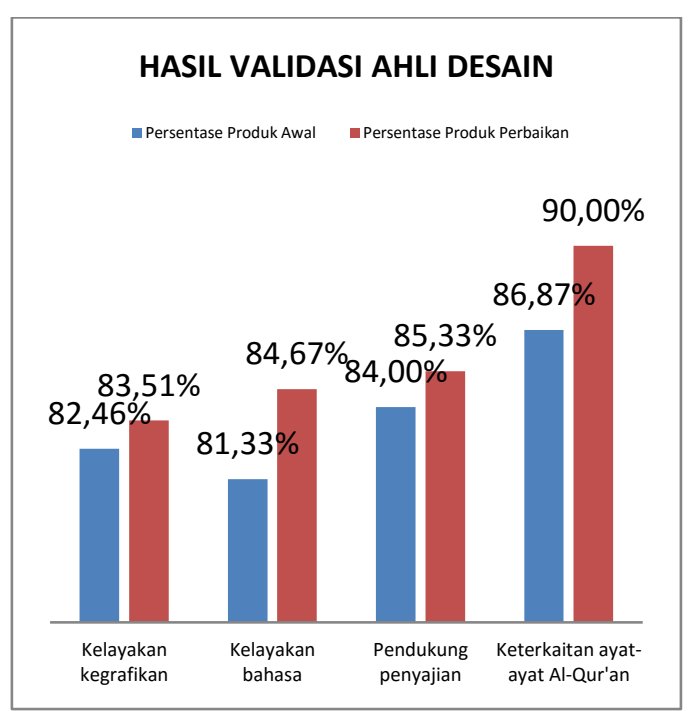

Gambar 2 Diagram tabulasi ahli desain 
Berdasarkan hasil validasi oleh ahli desain pada produk awal diperoleh skor total 211 dengan presentase $83 \%$ dan berada pada kriteria validasi "sangat baik". Setelah produk direvisi dilakukan validasi kembali, diperoleh skor total 218 dengan presentase $85 \%$ dan berada pada kriteria validasi "sangat baik", terjadi peningkatan skor setelah produk direvisi.

\section{c. Penilaian guru}

Pada ujicoba penilaian terhadap 3 guru IPA, dianalisis 10 indikator instrumen meliputi : 1) pendekatan penulisan, 2) kebenaran materi dan konsep, 3) kedalaman dan keluasan materi, 4) bahasa dan kejelasan kalimat, 5) daya tarik, 6) konsisten, 7) format, 8) bentuk dan ukuran huruf, 9) evaluasi, 10) glosarium.Tabulasi hasil penilaian guru IPA disajikan dalam bentuk diagram sebagai berikut ini:

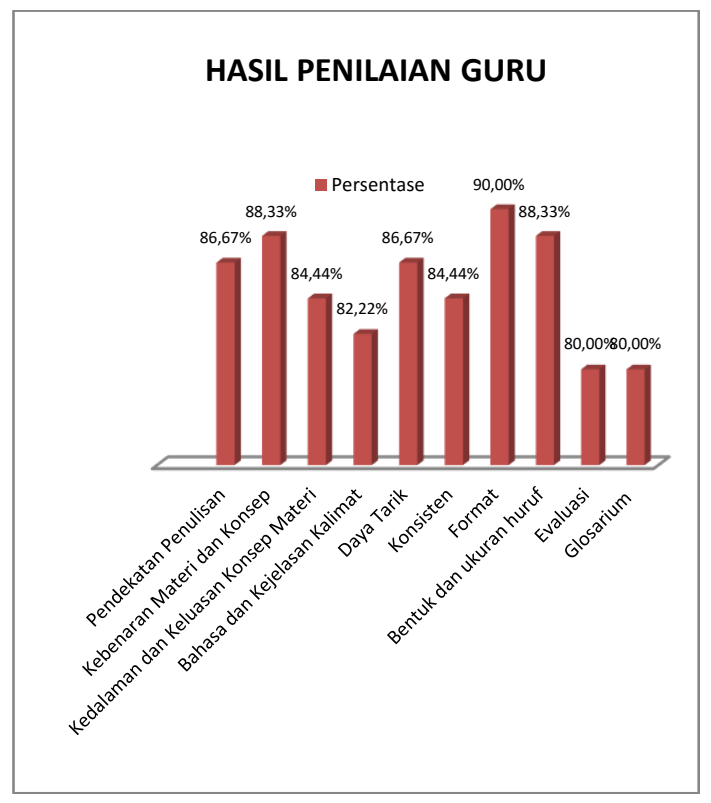

Gambar 3. Diagram Tabulasi Penilaian Guru

Berdasarkan hasil penilaian 3 guru IPA diperoleh skor total 373 dengan presentase $86 \%$ dan berada pada kriteria "sangat baik/sangat menarik".

\section{d. Respon Siswa}

Hasil ujicoba terhadap siswa dapat dilihat pada tabel dibawah ini:

Tabel 2 Tabulasi hasil uji kelompok kecil

\begin{tabular}{|c|c|c|}
\hline No & Indikator Angket & Skor \\
\hline 1 & Tampilan fisik modul & 558 \\
\hline 2 & Penggunaan bahasa & 112 \\
\hline 3 & Keluasan materi & 232 \\
\hline 4 & Penyampaian materi & 111 \\
\hline 5 & Evaluasi & 106 \\
\hline 6 & $\begin{array}{l}\text { Kesesuaian konsep ayat-ayat } \\
\text { Al-Qur'an }\end{array}$ & 114 \\
\hline 7 & $\begin{array}{l}\text { Penerapan konsep ayat-ayat } \\
\text { Al-Qur'an }\end{array}$ & 233 \\
\hline 8 & Motivasi Islami & 220 \\
\hline 9 & Penerapan konsep STAD & 583 \\
\hline & Jumlah skor total & 2269 \\
\hline & Skor Maksimal & 3000 \\
\hline & Persentase & $76 \%$ \\
\hline
\end{tabular}

Berdasarkan tabulasi hasil ujicoba kelompok kecil terhadap 30 siswa diperoleh skor total 2269 dengan presentase $76 \%$ dan berada pada kriteria "menarik".

Hasil uji coba lapangan dapat di lihat pada tabel dibawah ini :

Tabel 3 Tabulasi hasil uji lapangan

\begin{tabular}{clc}
\hline No & \multicolumn{1}{c}{ Indikator Angket } & Skor \\
\hline 1 & Tampilan fisik modul & 1818 \\
\hline 2 & Penggunaan bahasa & 360 \\
\hline 3 & Keluasan materi & 736 \\
\hline 4 & Penyampaian materi & 352 \\
\hline 5 & Evaluasi & 352 \\
\hline \multirow{2}{*}{6} & $\begin{array}{l}\text { Kesesuaian konsep ayat-ayat } \\
\text { Al-Qur'an }\end{array}$ & 366 \\
\hline \multirow{2}{*}{7} & $\begin{array}{l}\text { Penerapan konsep ayat-ayat Al- } \\
\text { Qur'an }\end{array}$ & 743 \\
\hline 8 & Motivasi Islami & 689 \\
\hline 9 & Penerapan konsep STAD & 1829 \\
\hline \multicolumn{2}{c}{ Jumlah skor total } & $\mathbf{7 2 4 5}$ \\
\hline \multicolumn{2}{c}{ Skor Maksimal } & $\mathbf{9 0 0 0}$ \\
\hline \multicolumn{2}{c}{ Persentase } & $\mathbf{8 1 \%}$ \\
\hline
\end{tabular}

Berdasarkan tabulasi hasil ujicoba lapangan terhadap 30 siswa diperoleh skor total 7245 dengan presentase $81 \%$ 
dan berada pada kriteria "sangat menarik".

Tujuan pertama pengembangan produk ini adalah mengembangkan modul IPA Terpadu terintegrasi ayat-ayat AlQur'an pada materi Air Sebagai Sumber Kehidupan. Berdasarkan hasil penelitian yang dilakukan penulis telah melalui validasi para ahli dan tahap uji coba dengan hasil sangat menarik, maka telah berhasil dikembangkan produk berupa modul IPA Terpadu terintegrasi ayat-ayat Al-Qur'an pada materi Air Sebagai Sumber Kehidupan. Kemenarikan terlihat dari respon positif dari tampilan fisik modul. Selain itu ketertarikan dapat dilihat dari respon positif terhadap muatan ayat-ayat Al-Qur'an pada materi yang disajikan.

Tujuan kedua penelitian pengembangan ini adalah untuk mengetahui kemenarikan Modul IPA Terpadu terintegrasi ayat-ayat Al-Qur'an pada materi Air Sebagai Sumber Kehidupan dalam pembelajaran.Modul ini disusun berdasarkan standar kompetensi, kompetensi dasar, serta indikator ketercapaian. Modul ini dilengkapi materi untuk presentasi guru, ayat-ayat Al-Qur' an yang disajikan sesuai dengan materi, lembar kerja siswa, lembar diskusi kelompok, lembar kuis individu, kolom penilaian predikat penghargaan kelompok, gambar, motivasi islami, info terkait materi, tokoh-tokoh IPA, rangkuman, glosarium, kunci jawaban yang dapat digunakan untuk pembelajaran siswa lebih menarik.

Modul yang dikembangkan telah divalidasi oleh 6 ahli yang meliputi 3 ahli materi dan 3 ahli desain.Setelah melalui tahap validasi beberapa ahli materi dan ahli desain selanjutnya modul diuji cobakan terhadap responden guru IPA, dan siswa kelompok kecil, serta uji coba lapangan untuk mengetahui kemenarikan modul.Dari hasil uji coba responden guru IPA, siswa kelompok kecil dan uji coba lapangan diperoleh penilaian dengan kriteria produk yang dikembangkan sangat baik atau sangat menarik.

\section{Pembahasan}

Berdasarkan hasil validasi oleh ahli materi, didapatkan saran perbaikan produk.Saran tersebut digunakan sebagai pertimbangan perbaikan pada produk awal. Adapun perbaikan produk awal sebagai berikut :

1) Penambahan ayat Al-Qur'an ke dalam modul pada materi lingkungan. Pada produk awal belum terdapat ayat AlQur'an, maka berdasarkan saran yang diberikan ditambahkan ayat Al-Qur'an ke dalam modul.

2) Penambahan gambar dan info terkini pada modul. Modul awal masih kurang gambar yang terkait pada materi. Pada modul awal juga masih kurang informasi terkini.

3) Penambahan persamaan panduan perolehan skor. Modul awal tidak terdapat persamaan panduan perolehan skor. Setelah perbaikan, telah ditambahkan persamaan panduan perolehan skor. Persamaan panduan perolehan skor ini berfungsi untuk mengukur kemampuan siswa secara mandiri

4) Soal kuis individu telah dirubah sesuai dengan kemampuan pemahaman siswa dan telah ditambahkan Al-Qur'an. Pada Kuis Individu I, dan II, modul awal belum terdapat soal yang memuat pertanyaan mengenai ayat AlQur'an.Setelah diperbaiki tiap soal pada kuis individu terdapat soal mengenai ayat Al-Qur'an dan tingkat kesulitan soal telah disesuaikan

Berdasarkan hasil validasi oleh ahli desain, didapatkan saran perbaikan produk.Saran tersebut digunakan sebagai pertimbangan perbaikan pada produk awal. Adapun perbaikan produk awal sebagai berikut:

1) Penggunaan jenis huruf pada modul hanya terdapat dua jenis. Jenis huruf 
yang digunakan pada modul awal adalah Times New Roman dan Berlin Sans FB Demi. Setelah perbaikan jenis huruf yang digunakan pada modul ada empat yaitu Times New Roman, Berlin Sans FB, Baskerville Old Face, Calisto MT, dan Bodoni, $M T$. Perubahan jenis huruf terdapat pada nama gambar dan sumber gambar.

2) Penyusunan paragraf perlu diperbaiki. Pada perbaikan ini, paragraf diatur agar simetris pada lembar modul. Paragraf juga diubah sesuai saran dari ahli untukjarak spasi sesudah dan sebelum paragraf.

3) Simbol yang digunakan kurang menarik, masih menggunakan simbol lama. Setelah diperbaiki, simbol yang sebelumnya titik empat diubah menjadi miniature Bumi.

4) Bagian glosarium masih banyak yang belum termuat, pada perbaikan ini di setiap akhir sub bab ditambahkan dengan glosarium.

\section{Kelebihan dan Kekurangan Produk Hasil Pengembangan.}

Produk hasil pengembangan ini memiliki beberapa kelebihan sebagai berikut ini :

a. Modul IPA Terpadu terintegrasi ayatayat Al-Qur'an pada materi Air Sebagai Sumber Kehidupan ini memberikan pengetahuan baru kepada siswa, baik dalam segi bidang studi IPA maupun keterkaitan materi dengan ayat-ayat Al-Qur'an.

b. Modul IPA Terpadu terintegrasi ayatayat Al-Qur'an pada materi Air Sebagai Sumber Kehidupan membuat pembelajaran lebih menarik.

c. Modul ini dilengkapi dengan materi yang lengkap, gambar, motivasi islami, tokoh IPA, info terbaru dan variasi evaluasi sehingga siswa dapat dengan mudah memahami sajian yang terdapat dalam modul. d. Modul IPA Terpadu terintegrasi ayatayat Al-Qur'an pada materi Air Sebagai Sumber Kehidupan ini efektif jika digunakan secara mandiri.

Produk pengembangan penelitian ini memiliki beberapa kelemahan sebagai berikut ini:

a. Modul ini tidak mudah digunakan pada sekolah-sekolah yang tidak bervisi Islami.

b. Materi dalam modul yang dikembangkan ini hanya terbatas 1 pokok bahasan.

\section{SIMPULAN DAN SARAN \\ Simpulan}

Modul IPA Terpadu terintegrasi ayat-ayat Al-Qur'an pada materi Air Sebagai Sumber Kehidupan yang dikembangkan dinilai sangat menarik untuk dijadikan bahan ajar, penilaian tersebut diperoleh berdasarkan validasi produk oleh ahli materi dan ahli desain serta uji coba kelompok kecil dengan responden guru IPA dan siswa, serta uji lapangan dengan responden siswa kelas VII SMP/MTs. Ketertarikan siswa pada modul ditunjukkan dari adanya respon positif siswa terhadap adanya muatan ayat-ayat Al-Qur'an dalam modul pembelajaran.

\section{Saran}

1) Guru hendaknya dapat menggunakan modul yang memuat metode-metode yang dapat menumbuhkan motivasi belajar siswa dan pengetahuan yang luas dalam pembelajaran.

2) Instansi sekolah hendaknya memiliki berbagai sumber belajar, baik sumber belajar yang memuat materi IPA secara sains maupun sumber belajar yang memuat materi IPA dalam sudut pandang sains dan agama. Terutama bagi instansi-instansi sekolah berbackgound agama Islam (MTs).

3) Perlu dikembangkan lebih lanjut modul IPA Terpadu dengan pokok 
bahasan lain serta menggunakan metode-metode yang dapat menumbuhkan motivasi dan keaktifan siswa dalam proses pembelajaran agar lebih menarik.

\section{DAFTAR PUSTAKA}

Arsyad, Azhar. (2011). Media Pembelajaran. Jakarta: Rajawali Pers.

Depdiknas, 2006. Kurikulum Tingkat Satuan Pendidikan (KTSP). Jakarta: Depdiknas.

Djudin, T. (2011). Menyisipkan NilaiNilai Agama dalam Pembelajaran Sains: Upaya Alternatif Memagari Aqidah Siswa. Khatulistiwa, 1(2).

Fatmawati, L. (2012). Pengembangan Bahan Ajar Modul Elektrokimia Untuk Siswa Sma Kelas Xii Dengan Pendekatan Inkuiri Terbimbing. Disertasi dan Tesis Program Pascasarjana UM.

Febriana, L. C. (2014). Pengembangan Lembar Kerja Siswa (LKS) Fisika Materi Tekanan Mencakup Ranah Kognitif, Afektif, dan Psikomotor
Sesuai Kurikulum 2013 Untuk Siswa SMP/MTs. SKRIPSI Jurusan FisikaFakultas MIPA UM.

Izzati, N., Hindarto, N., \& Pamelasari, S. D. (2013). Pengembangan Modul Tematik dan Inovatif Berkarakter pada Tema Pencemaran Lingkungan untuk Siswa Kelas VII SMP. Jurnal Pendidikan IPA Indonesia, 2(2).

Mushaf Aminah. (2012). Al-Qur'an dan Terjemahannya, Jakarta: Alfatih.

Thayyarah, N. (2014). Sains dalam AlQur'an. Jakarta: Penerbit Zaman.

Reid, D. (1984). Readability and science worksheets in secondary schools. Research in Science \& Technological Education, 2(2), 153-165.

Sugiyono. (2012). Metode Penelitian Kuantitatif Kualitatif dan $R \& D$. Bandung: Alfabeta.

Trianto. (2012). Model Pembelajaran Terpadu. Jakarta: PT Bumi Aksara.

Yuberti. (2014). Teori Belajar dan Pembelajaran Dalam Pendidikan, Bandar Lampung: Anugrah Utama Raharja. 